\title{
Metode Bercerita dalam Pembelajaran Pendidikan Agama Islam
}

\author{
SYAHRAINI TAMBAK \\ Fakultas Agama Islam (FAI) Universitas Islam Riau (UIR) Pekanbaru \\ Jl. Kaharuddin Nasution, No. 113, Perhentian Marpoyan Pekanbaru 28284 \\ e-mail: syahraini_tambak@yahoo.co.id
}

\begin{abstract}
Abstrak: Dalam proses pembelajaran diperlukan metode-metode yang tepat. Pemilihan metode yang tepat akan menjadikan proses pendidikan termasuk pendidikan agama islam berjalan dengan efektif. Dalam pendidikan agama islam, banyak terkandung nilai-nilai sejarah yang berupa cerita kejadiankejadian masa lalu baik dimasa ketika zaman Rasulullah SAW maupun setelah beliau wafat. Panjangnya kisah-kisah kehidupan masa lampau akan sangat sulit dipahami oleh peserta didik apabila hanya dengan membaca. Oleh karena itu diperlukan sebuah metode yang paling tepat untuk menceritakan kisah perjalanan perkembangan agama islam sehingga peserta didik dapat memahami secara mendalam dan efisien. Metode ini adalah metode bercerita. Walaupun metode bercerita ini merupakan metode yang hanya berpusat kepada guru, tetapi apabila dilakukan dengan intonasi yang menarik dan isi ceritanya tepat, maka akan lebih efektif bagi siswa dalam pemahaman cerita sejarah dibandingkan dengan metode lainnya.
\end{abstract}

Kata Kunci: Metode bercerita, Pembelajaran, Pendidikan Agama Islam

\section{PENDAHULUAN}

Nabi Muhammad SAW dalam memberikan pelajaran kepada para sahabat seringkali menggunakan metode cerita tentang hal-hal yang berkaitan dengan kehidupan dan kejadian-kajadian masa lalu. Penggunaan metode itu dianggap akan lebih membekas dalam jiwa orangorang yang mendengarkannya serta menarik perhatian mereka (Guddah, tt.: 194). Allah SWT sesungguhnya telah mengenalkan metode pembelajaran seperti ini kepada Rasulullah SAW seperti firman-Nya yang termaktub dalam al-Qur'an:

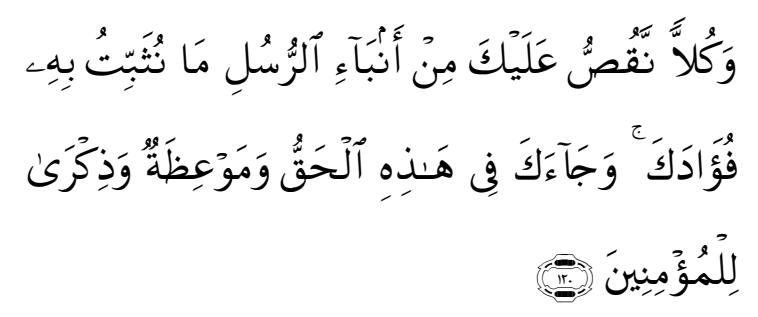

Artinya: "Dan semua kisah dari Rasulrasul Kami ceritakan kepadamu, ialah kisah-kisah yang dengannya Kami teguhkan hatimu; dan dalam surat ini telah datang kepadamu kebenaran serta pengajaran dan peringatan bagi orangorang yang beriman".(QS. Hud, 11: 120).

Bercerita adalah kegiatan yang dilakukan oleh seorang guru pendidikan agama Islam secara lisan kepada peserta didik dengan alat atau tanpa alat tentang materi pendidikan 
agama Islam yang diajarkan dalam bentuk pesan, informasi, atau dongeng untuk diperdengarkan dengan rasa menyenangkan.

Di sini peran seorang guru pendidikan agama Islam dalam menggunakan metode berserita sungguh urgen. Peserta didik tertarik atau tidak bergantung pada proses penyampaian yang dilakukan oleh guru pendidikan agama Islam. Menikmati sebuah cerita mulai tumbuh pada seorang anak semenjak ia mengerti akan peristiwa yang terjadi di sekitarnya dan setelah memorinya mampu merekam beberapa kabar berita. Masa tersebut terjadi pada usia 4-5 tahun yang ditandai oleh berbagai kemampuan.

\section{PENGERTIAN METODE BERCERITA}

Metode bercerita, secara etimologi berasal dari bahasa Arab yaitu kata qashash merupakan bentuk jamak dari qishash, masdar dari qassa, yaqussu, artinya adalah menceritakan dan menelusuri/mengikuti jejak (Manzhur, 711H: 148). Dalam al-Qur'an lafaz qashash mempunyai makna yaitu kisah atau cerita. Qashash artinya berita alQur'an tentang umat terdahulu (Abdullah, 1994: 205).

Metode bercerita adalah cara penyampaian atau penyajian materi pembelajaran secara lisan dalam bentuk cerita dari guru kepada anak didik. Dalam kegiatan pelaksanaannya metode bercerita dilaksanakan dalam upaya memperkenalkan, memberikan keterangan, atau penjelasan tentang hal-hal baru dalam rangka menyampaikan pembelajaran yang dapat mengembangkan berbagai kompetensi dasar (Dhieni, 2008: 66).

Dari segi istilah, bercerita menurut Gorden dan Brown seperti dikutip Otib Satibi Hidayat merupakan cara untuk meneruskan warisan budaya dari satu generasi ke generasi berikutnya (Hidayat, 2006: 417). Bercerita juga dapat menjadi media untuk menyampaikan nilai-nilai yang berlaku di masayarakat. Seorang pendongeng yang baik akan menjadikan cerita sebagai sesuatu yang menarik dan hidup. Keterlibatan anak terhadap dongeng yang diceritakan akan memberikan suasana yang segar, menarik, dan menjadi pengalaman yang unik bagi anak (Hidayat, 2006: 417).

Metode bercerita ini oleh Nur Uhbiyati disebut yaitu dengan mengisahkan peristiwa sejarah hidup manusia di masa lampau yang menyangkut ketaatannya atau kemungkarannya dalam hidup terhadap perintah Tuhan yang dibawakan oleh Nabi Muhammad SAW atau Rasul yang hadir di tengah mereka (Uhbiyati, 1997: 111). Sementara Samsul Nizar dan Zaenal Efendi Hasibuan menyebutkan metode bercerita ini dengan metode kisah yang digambarkan sebagai metode dengan menggunakan ceritacerita yang dapat menghubungkan materi pelajaran dengan kajian masa lampau agar lebih dapat dan mudah dipahami oleh peserta didik dalam alam lebih nyata (Nizar \& Hasibuan, 2011: 78).

Menurut Poerwadarminta, seperti dikutip Samsul Nizar dan Zaenal Efendi Hasibuan (2011: 78), metode bercerita mengandung arti suatu cara dalam menyampaikan materi pelajaran dengan menuturkan secara kronologis tentang bagaimana terjadinya sesuatu hal baik yang sebenarnya terjadi ataupun hanya rekaan saja. Metode bercerita sangat dianjurkan dalam upaya pembinaan akhlak peserta didik. Melalui cerita-cerita tersebut peserta didik diharapkan memiliki akhlak mulia sesuai dengan akhlak dan sikap teladan 
yang terdapat pada suatu kisah yang dikisahkan.

Dengan demikian dengan menggunakan metode bercerita dalam pembelajaran PAI yang bersumber dari al-Qur'an akan menjadi semacam kilas balik di mana murid-murid dapat bercermin tentang kejadian masa lalu sambil melihat pada masa sekarang. Peserta didik dapat mengambil pelajaran dari kisah-kisah tersebut sekaligus memetik hikmah untuk perbaikan dirinya di masa depan. Menurut Nur Uhbiyati dan Abu Ahmadi, menggunakan berbagai cerita maupun peristiwa dalam proses pendidikan agama Islam memberikan pesan pada anak secara tidak langsung mengajaknya bercermin kepada fakta dan data di masa dahulu untuk melihat dirinya (Uhbiyati \& Ahmadi, 1997: 217).

Al-Qur'an pun banyak mengabadikan kisah-kisah penting dan bermanfaat yang terjadi dalam sejarah dengan menghidupkan dalam firmanNya untuk memberanikan hati manusia dalam kehidupan, meningkatkan semangat perjuangan, motivasi belajar, dan menumbuhkan sikap optimistis. Metode bercerita ini tampaknya efektif dipergunakan dalam pengajaran pendidikan agama Islam karena dapat merangsang perasaan peserta didik dengan bercermin pada sejarah sehingga mereka dapat memposisikan siapa dirinya dan apa yang telah diperbuat.

Berdasarkan berbagai pendapat di atas dapat ditegaskan di sini bahwa metode bercerita dalam pembelajaran PAI adalah cara penyajian materi pembelajaran secara lisan dengan menceritakan peristiwa sejarah hidup manusia di masa lampau yang menyangkut ketaatan untuk diteladani atau kemungkaran untuk ditinggalkan yang bersumber dari alQur'an dan al-Hadits menggunakan alat peraga pendidikan untuk meningkatkan pemahaman dan pembinaan kepribadian peserta didik.

Cerita mempunyai daya tarik yang dapat menyentuh perasaan anak. Sebab cerita itu pula kenyataannya dapat merajut hati manusia dan dapat mempengaruhi perasaan dan pula kehidupan mereka. Cerita tentang kisah-kisah yang mengandung hikmah sangat efektif untuk menarik perhatian anak dan merangsang otaknya agar bekerja dengan baik, bahkan metode ini dianggap baik dalam merangsang pola pikir anak. Karena dengan mendengar cerita, pemikiran dan emosional anak terangsang sehingga tertarik menyerap pesan yang disampaikan tanpa dipaksakan. Cara seperti ini telah dicontohkan oleh Rasulullah SAW sejak dahulu, "beliau sering bercerita tentang kisah-kisah kaum terdahulu kepada sahabatnya dengan tujuan dapat mengambil hikmah dan pelajaran" (Hafizh, 1998: 301).

Cerita yang dikemas menarik dan disesuaikan dengan psikologi perkembangan anak menggiring dirinya mengikuti jejak cerita, mengetahui bahwa ia berada di pihak ini atau itu dan memposisikan dirinya dengan posisi tokoh cerita. Implikiasi dari metode ini mengakibatkan anak menimbulkan rasa simpati dan mengikutinya demikian juga sebaliknya tidak tertarik dan akan membencinya.

Pada anak usia pra-sekolah, metode ini sungguh baik diterapkan karena dengan cerita anak dapat memperhatikan dan melibatkan diri dengan cerita-cerita yang didengarkan dari orang tua walaupun kemampuan untuk mengungkapkan isi cerita belum sempurna. Orang tua dapat memberikan cerita mulai dari hal-hal yang sederhana. Menurut Muhammad Quthb, dengan cerita anak mempunyai 
daya tarik yang menyentuh perasaan dan mempunyai pengaruh terhadap jiwa anak. Semua bentuk cerita ini disesuaikan dengan tarap perkembangan jiwa anak (Qutb, 1993: 347).

Manusia memiliki sifat alamiah untuk menyenangi cerita dan pengaruhnya sangat besar terhadap perasaan manusia. Oleh karena itu sungguh wajar apabila cerita dijadikan salah satu metode dalam pendidikan. Al-Qur'an mengandung berbagai cerita tentang Nabi dan Rasul serta tokohtokoh terdahulu baik yang ingkar maupun yang beriman kepada Allah SWT untuk diteladani manusia agar mengambil pelajaran dari sejarah tersebut. Metode ini merupakan faktor penting dalam pendidikan karena ia bersifat mengasah intelektualitas dan amat berpengaruh dalam menanamkan nilai-nilai dan moralitas serta humanisme yang benar. Cerita yang disampaikan itu disesuaikan dengan tingkat perkembangan anak (dalam Ismail, 2001: 48).

Sesuai dengan penelitian Ernest Harms bahwa tingkat kemampuan pada anak yang paling randah adalah tingkat cerita. Pada tingkat ini konsep mengenai sesuatu lebih banyak dipengaruhi oleh fantasi dan emosi. Pada tingkat perkembangan ini menghayati sesuatu sesuai dengan tingkat perkembangan intelektualitas anak. Kehidupan masa ini masih banyak dipengaruhi kehidupan fantasi (Jaliluddin, 1998: 66). Guru pendidikan agama Islam dalam menerapkan metode cerita ini dalam pendidikan agama Islam di sekolah dituntut mengetahui sikap fantasi yang dimiliki anak. Tidak memberikan cerita-cerita yang sulit dimengerti akan tetapi cerita yang mudah difahami anak.

\section{DASAR METODE BERCERITA DALAM AL-QUR'AN}

Allah SWT dalam memberikan pelajaran pada manusia banyak menggunakan metode bercerita yakni menceritakan kisah-kisah yang baik untuk diteladani dan menceritakan kisah-kisah yang buruk untuk dihindarkan. Hal ini misalnya dapat dilihat pada sebuah ayat yang menggambarkan nilai pedagogis dalam sejarah diungkapkan oleh Allah SWT dan ini sekaligus sebagai landasan metode berserita dalam al-Qur'an, sebagai berikut:

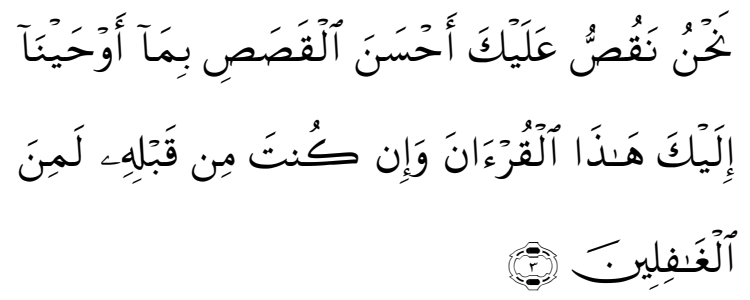

Artinya: "Kami menceritakan kepadamu kisah yang paling baik dengan mewahyukan Al-Quran ini kepadamu, dan sesungguhnya kamu sebelum (kami mewahyukan)nya adalah termasuk orang-orang yang belum mengetahui". (QS. Yusuf, 12: 3).

Kata yang menggambarkan secara langsung pada metode bercerita adalah "naqushshu" yang berarti Kami menceritakan. Naqushshu berasal dari kata qashsha-yaqushshu bentuk fi'il madhi dan fi'il mudhari', artinya menceritakan. Dalam ayat di atas tampak secara jelas bahwa terdapat guru yang mengajarkan yaitu Allah SWT sendiri sebagai sebagai guru memberikan isi cerita yang terbaik "ahsanal qashash" sebagai materi pembelajaran. Materi pembelajaran yang diajarkan dengan metode bercerita itu adalah kisah yang paling baik yaitu yang terdapat dalam wahyu Allah SWT al-Qur'an. Al-qashash menurut Quraish Shihab adalah bentuk jamak dari qishshah/kisah. Ia terambil dari kata qashsha yang pada mulanya 
berarti mengikuti jejak. Kisah adalah upaya mengikuti jejak peristiwa yang benar-benar terjadi atau imajinatif sesuai dengan urutan kejadiannya dan dengan jalan menceritakannya satu episode atau episode demi episode (Shihab, 2012: 12).

Ahsanal qashash dapat dimaknai sebagai materi pembelajaran yang diajarkan melalui metode bercerita. Ahsanal qashash adalah kisah yang paling baik. Ahsanal qashash pada ayat ini digambarkan dalam buku Syamil alQur'an Miracle The Reference adalah kisah Nabi Yusuf as. Kisah Nabi Yusuf as adalah sebaik-baik kisah dalam perjalanan sejarah hidup manusia. Nabi Yusuf as. (dikenal dalam Bibel sebagai Josef) adalah salah seorang nabi yang hidupnya banyak diceritakan dalam alQur'an. Nyaris seluruh bagian surah Yusuf, salah satu yang terpanjang di dalam al-Qur'an, mengisahkan kehidupannya dan keluarganya. Pada awal surah ini, Allah mengungkapkan bahwa kisah hidupnya mengandung tanda-tanda bukti-bukti, dan hikmah yang penting. "Sesungguhnya, ada tanda-tanda kekuasaan Allah pada (kisah) Yusuf dan saudara-saudaranya bagi orang-orang yang bertanya" (QS. Yusuf, 12: 7). Sebagaimana halnya dengan nabi-nabi lainnya, orang-orang yang beriman yang membaca kisah Nabi Yusuf as. akan menemukan banyak hal yang menenteramkan dan mendapatkan banyak pelajaran (Laksana, 2010: 468).

Quraish Shihab menafsirkan ayat ini dengan mengatakan bahwa kini alQur'an mengajak kita menuju kepada kisah yang diwahyukan ini. Allah SWT berfirman, "Kami tahu, masyarakat Arab yang engkau temui, wahai Muhammad, termasuk sahabatsahabatmu, bermohon kiranya engkau mengisahkan kepada mereka suatu kisah. Orang-orang Yahudi pun ingin mendengarnya. Karena itu, Kami kini dan juga masa yang akan datang akan menceritakan kepadamu kisah untuk memenuhi permintaan mereka dan juga untuk menguatkan hati dan agar mereka manarik pelajaran. Kisah ini adalah kisah yang terbaik gaya, kandungan, dan tujuannya. Itu Kami lakukan dengan mewahyukan kepadamu al-Qur'an ini, dan sesungguhnya engkah sebelumnya, yakni sebelum Kami mewahyukannya, sungguh termasuk kelompok orang-orang yang tidak mengetahui. Betapa engkau, wahai Muhammad, bahkan betapa kamu semua mengetahui, padahal kamu adalah masyarakat yang tidak pandai membaca. Kalaupun pandai, peristiwa yang dikisahkan ini sudah terlalu jauh masanya sehingga perincian yang diketahui oleh siapa pun sungguh banyak yang keliru dan tidak sesuai dengan kenyataan (Shihab, 2012:12).

Di ujung ayat ditemukan kata alghafilin. Menurut Quraish Shihab, kata al-ghafilin terambil dari kata ghafala yang makna dasarnya berkisar pada ketertutupan. Dari sini simpul yang berfungsi menutup sesuatu dinamai ghilaf; tanah yang tidak dikenal karena tanpa tanda-tanda dinamai ghulf, dank arena ketiadaan tanda itulah maka orang tidak mengetahuinya. Kata ghafil biasa juga diartikan lengah, yang tidak mengetahui bukan karena kepicikan akal, akan tetapi karena kurangnya perhatian (Shihab, 2012:12). Apabila kata "naqushshu" dikaitkan dengan kata "al-ghafilin" artinya orang-orang yang belum mengetahui, hal itu menggambarkan adanya proses pembelajaran untuk mengajari manusia yang belum mengetahui dengan materi kisah-kisah yang terdapat di dalam alQur'an menggunakan metode bercerita. Kata "al-ghafilin" diujung ayat tersebut menggambarkan bahwa manusia sebelum mendapatkan cerita yang 
bersumber dari apa yang diwahyukan oleh Allah SWT (al-Qur'an) tidak memiliki pengetahuan.

Ayat lain yang dijadikan sebagai landasan metode bercerita yang memiliki relevansi dengan ayat di atas dapat dilihat firman Allah SWT yang menceritakan kisah kepada manusia, yaitu:

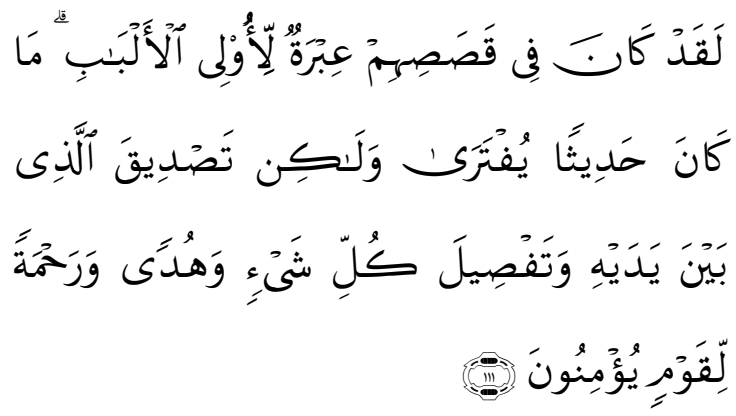

Artinya: "Sesungguhnya pada kisahkisah mereka itu terdapat pengajaran bagi orang-orang yang mempunyai akal. Al Quran itu bukanlah cerita yang dibuat-buat, akan tetapi membenarkan (kitab-kitab) yang sebelumnya dan menjelaskan segala sesuatu, dan sebagai petunjuk dan rahmat bagi kaum yang beriman". (QS. Yusuf, 12: 111).

Akhirnya, sekali lagi menurut Quraish Shihab ketika menafsirkan ayat di atas, Allah SWT menegaskan tentang kisah Nabi Yusuf as. ini dan kisah-kisah para rasul yang lain disampaikan-Nya bahwa demi Allah, sungguh pada kisahkisah mereka terdapat pengajaran bagi orang-orang yang mempunyai akal. Ia, yakni al-Qur'an mengandung kisahkisah mereka, bukanlah cerita yang dibuat-buat sebagaimana dituduhkan oleh mereka yang tidak percaya, akan tetapi kitab suci itu membenarkan kitab-kitab suci dan peristiwa-peristiwa yang sebelumnya dan menjelaskan segala sesuatu dalam bentuk prinsipprinsip segala yang dibutuhkan umat manusia menyangkut kemaslahatan dunia dan akhirat mereka, dan di samping itu ia juga sebagai petunjuk dan rahmat bagi kaum yang ingin beriman (Shihab, 2012: 193-194).
Metode bercerita dalam ayat kedua ini (QS. Yusuf, 12: 111) melengkapi ayat sebelumnya di mana materi yang disampaikan adalah kisahkisah yang harus menjadi pelajaran bagi peserta didik yang menerima pembelajaran tersebut. Hal ini menggambarkan bahwa penggunaan metode bercerita dengan materinya haruslah dapat menjadikan peserta didik mengambil pelajaran karena dalam setiap isi cerita yang dalam bentuk kisah tersebut terdapat manfaat besar untuk direnungkan dan diambil hikmah. Maka isi materi yang diceritakan haruslah dapat membuat peserta didik mengambil hikmah dan ini terdapat dalam kata "fi qashashihim 'ibrah". Mengambil pelajaran dan hikmah dari isi cerita atau kisah-kisah hanyalah dapat dilakukan bagi mereka yang mempunyai akal dan menggunakan akalnya dengan baik seperti terlihat dari kata "li ulil al-bab" artinya orang-orang yang mempunyai akal. Ini pulalah yang menjadi penting untuk diperhatikan oleh guru PAI dalam menggunakan metode bercerita untuk menyentuh akal pikiran manusia agar dapat menerima isi yang diceritakan.

Hal di atas menggambarkan landasan utama yang dapat dijadikan sebagai sumber penting dalam alQur'an untuk metode bercerita. Lebih lanjut ayat tersebut menyiratkan adanya unsur pendidikan dengan metode bercerita dengan mengambil cerita-cerita yang terdapat di dalam alQur'an. Di sini tampak jelas bahwa bila Anda sebagai guru atau calon guru maka penggunaan metode bercerita hendaklah mengambil cerita tersebut dari cerita-cerita yang terdapat di dalam al-Qur'an. Semua kejadian yang terjadi hari ini haruslah kembali melihat hal semisal cerita yang terdapat di dalam al-Qur'an. Terkait hal ini misalnya dapat dilihat cerita pemimpin 
yang zalim, akhlak buruk, hakim yang curang dan lain sebagainya dapat tergambar kisah-kisah tersebut dengan jelas dan gamblang di dalam al-Qur'an.

\section{SITUASI PENGGUNAAN}

Situasi penggunaan metode pembelajaran PAI sangat penting untuk diperhatikan oleh guru atau calon guru PAI di sekolah. Guru PAI harus betulbetul melihat dan menyesuaikan metode bercerita ini dengan situasi penggunaan. Hal dibutuhkan untuk menjadikan metode bercerita yang digunakan tepat sasaran dan dapat menjadikan materi pembelajaran PAI diterima dan dipahami dengan baik oleh peserta didik. Di bawah ini dapat diketengahkan situasi penggunaan metode bercerita dalam pembelajaran PAI.

\section{Mendidikan Keteladanan}

Anda sebagai seorang guru PAI atau calon guru PAI di sekolah harus jeli melihat materi yang akan diajarkan pada peserta didik. Apabila materi yang diajarkan memang untuk menggiring peserta didik pada penguasaan akhlak dan moral maka metode bercerita sangat tepat untuk digunakan. Sebab dengan menceritakan sebuah kisah yang sesuai dengan silabus pembelajaran PAI biasanya peserta didik lebih terikat dan mengikuti ide cerita sembari membandingkan dengan dirinya hari ini. Bila demikian halnya maka keteladanan yang ada dalam cerita diharapkan dapat diresapi oleh peserta didik dalam kehidupan seharihari.

Mendidikan keteladanan melalui bercerita dapat juga dikemas dengan media film adalah metode yang paling baik dalam menyampaikan pendidikan Islam. Karena menurut Onong Uchjana Efendi, film adalah medium komunikasi masa yang ampuh sekali, bukan hanya untuk hiburan tapi juga penerangan dan pendidikan (Efendi, 1993: 209). Karena dengannya, orang tidak sadar bahwa dia sedang belajar, sehingga tidak ada beban bagi seseorang dalam mengikutinya. Oleh karena itulah, banyak ayat al-Qur`an dalam menyampaikan pesan pendidikan kepada manusia menggunakan cerita.

\section{Menarik Perhatian dan Merangsang Otak}

Cerita tentang kisah-kisah yang mengandung hikmah sangat efektif untuk menarik perhatian anak dan merangsang otaknya agar bekerja dengan baik, bahkan metode ini dianggap yang terbaik dari cara-cara yang lain dalam mempengaruhi pola bantu anak. Karena dengan mendengarkan cerita, anak didik akan merasakan senang sekaligus menyerap nilai-nilai pendidikan agama Islam tanpa merasa dipaksakan. Cara seperti ini, menurut Muhammad Nur Abdul Hafizh, telah dicontohkan oleh Rasulullah SAW sejak dahulu. Beliau sering bercerita tentang kisah-kisah kaum terdahulu agar mengambil hikmah dan pelajaran darinya (Hafizh, 1998: 301).

\section{Menanamkan Nilai Akhlak dan Emosional}

Dalam menanamkan nilai akhlak dan emosional Rasulullah SAW menggunakan metode cerita ini, menurut Yusuf al-Qardawi, dalam menjelaskan nilai-nilai dan maknamakna tertentu serta menegaskannya, seperti penjelasan tentang nilai-nilai keikhlasan dalam menyelamatkan manusia dari kehancuran, yang tersebut dalam kisah tiga orang penghuni syurga, yaitu orang buta, cacat, dan 
berpenyakit. Penjelasan tentang rahmat Allah SWT yang meliputi seluruh alam sampai binatang, yang beliau umpamakan dengan kisah seseorang yang memberikan minuman kepada anjing yang menjulurkan lidahnya karena kehausan, lalu berterima kasih kepada Allah SWT dan diampuni dosanya (Al-Qardhawi, 1994: 115).

Metode bercerita dapat mengungkapkan peristiwa yang mengandung nilai-nilai pendidikan moral, rohani, dan sosial untuk anak didik baik cerita bersifat kebaikan, maupun kezaliman, atau juga ketimpangan jasmani-rohani, materialspritual yang dapat melumpuhkan semangat manusia. Metode bercerita ini sangat efektif sekali, terlebih lagi bila sasarannya anak didik yang masih dalam perkembangan "fantastik". Dengan mendengarkan suatu cerita, kepekaan jiwa dan perasaan anak didik dapat tergugah. Pemberikan stimulus pada anak didik dengan bercerita tersebut secara otomatis mendorong anak didik untuk berbuat kebaikan, dan dapat membentuk akhlak mulia serta membina rohani (iman dan takwa) (Akbarizan, 2008: 156).

\section{Anak Usia Pra-Sekolah}

Pada anak usia pra-sekolah, metode ini sungguh baik diterapkan karena dengan cerita anak dapat memperhatikan dan melibatkan diri dengan cerita-cerita yang didengarkan dari guru PAI walaupun kemampuan untuk mengungkapkan isi cerita belum sempurna. Orang tua dapat memberikan cerita mulai dari hal-hal yang sederhana. Di samping itu, menurut Muhammad Quthb dengan cerita, anak mempunyai daya tarik yang menyentuh perasaan dan mempunyai pengaruh terhadap jiwa anak. Semua bentuk cerita ini disesuaikan dengan tarap perkembangan jiwa anak (Qutb, 1993: 347).

\section{Peserta didik yang Memiliki Kecerdasan Verbal-Linguistik}

Peserta didik yang memiliki kecerdasan verbal linguistik cenderung memiliki kemampuan retoris bahasa atau kemampuan untuk meyakinkan orang lain dari serangkaian tindakan, potensi dalam mengingat bahasa, atau kemampuan untuk mengingat bahasa dalam mengingat daftar atau proses; kapasistas bahasa untuk menerangkan konsep dan nilai metofora dalam melakukannya, dan penggunaan bahasa untuk merefleksikan bahasa atau menggunakannya dalam analisis "metalinguistik" (Campbell, 2002: 10).

Peserta didik yang memiliki kecerdasan verbal-linguistik ini sangat berakar dalam perasaan kita mengenai kompetensi dan kepercayaan diri. Makin banyak anak-anak latihan dalam kecerdasan ini di tempat yang kondusif, makin mudah mereka mengembangkan keterampilan-keterampilan verbal ini yang akan bermanfaat bagi mereka sepanjang hayat (Campbell, 2002: 14). Guru PAI dapat memberikan model yang kuat melalui permainan kata-kata dan lainnya dan ini dapat dilakukan dengan menggunakan metode bercerita. Oleh karena kecerdasan verbal-linguistik ada pada pengolahan kata-kata atau berbicara maka dengan mendengarkan cerita maka peserta didik akan memiliki banyak perbendaharaan kata dan dapat mengambil hikmah dari isi cerita tersebut.

\section{KELEBIHAN METODE BERCERITA}

Metode bercerita memiliki kelebihan dibanding dengan metode lainnya dalam proses pembelajaran 
pendidikan agama Islam. Kelebihan metode bercerita ini memiliki kelebihan dalam pembelajaran PAI, yaitu; dapat mengaktifkan dan membangkitkan semangat peserta didik; mengarahkan emosi menyatu pada kesimpulan; memikat; mempengaruhi emosi; dan membekas dalam jiwa dan menarik perhatian.

\section{Mengaktifkan dan Membangkitkan Semangat Peserta didik}

Kelebihan yang pertama ini di mana metode bercerita dapat mengaktifkan dan membangkitkan semangat peserta didik. Penggunaan metode bercerita dalam kelebihan ini dapat membangkitkan semangat peserta didik dalam proses pembelajaran. Semangat peserta didik dalam belajar menjadi hal penting untuk dibangkitkan hingga dapat belajar dengan baik sesuai dengan harapan yang sesungguhnya. Hal ini juga harus diperhatikan oleh dalam proses penggunaan metode bercerita dalam aktivitas belajar pendidikan agama Islam.

\section{Mengarahkah Emosi}

Kelebihan kedua ini mengarahkan semua emosi hingga menyatu pada satu kesimpulan yang menjadi akhir cerita. Emosi peserta didik menjadi bagian penting sebagai kelebihan dari metode bercerita ini. Sebab biasanya cerita itu yang tersentuh adalah emosi peserta didik dan ini pulalah yang harus dibangkitkan oleh guru pendidikan agama Islam. Kisah dapat mengaktifkan dan membangkitkan kesadaran pembaca tanpa cerminan kesantaian dan keterlambatan sehingga dengan kisah, setiap pembaca akan senantiasa merenungkan makna dan mengikuti berbagai situasi kisah tersebut sehingga pembaca terpengaruh oleh tokoh dan topik kisah tersebut (An-Nahlawi, 1992: 242).

\section{Mengandung Pendengaran untuk untuk mengikuti dan merenungkan maknanya}

Metode cerita selalu memikat karena mengandung pendengaran untuk mengikuti peristiwanya dan merenungkan maknanya. Metode bercerita menekankan pada proses verbal di mana guru menceritakan kisah dengan lisan, dan itu menandakan bahwa pendengaran dari peserta didik untuk mengikuti peristiwa tersebut dituntut sangat teliti. Ketelitian dalam mendengarkan alur dan isi cerita membuat peserta didik tak dapat mengelak untuk juga merenungkan maknanya. Bila peserta didik di saat mendengar tak juga sekaligus merenungkan maknanya, maka cerita tersebut hanyalah tinggal cerita tak tau alur dan tujuan cerita. Sebab bila peserta didik hanya berpura-pura mendengar cerita maka itu hanyalah membuat peserta didik seperti beo yang tak tau arti dan tujuan pembicaraan. Maka dengan demikian cerita dapat selalu memikat pendengarnya untuk memperhatikan dan mendengarkan.

\section{Mempengaruhi Emosi}

Kelebihan keempat dapat mempengaruhi emosi seperti takut, perasaan diawasi, rela, senang, atau benci sehingga bergelora dalam lipatan cerita. Kisah-kisah Qur`ani mampu membina perasaan ketuhanan melalui cara-cara berikut: (1) Mempengaruhi emosi, seperti takut, perasaan diawasi, rela dan lain-lain. (2) Mengarahkan semua emosi tersebut sehingga menyatu pada satu kesimpulan yang menjadi akhir cerita.

Mengikutsertakan unsur psikis yang 
membawa pembaca larut dalam setting emosional cerita sehingga pembaca, dengan emosinya, hidup bersama tokoh cerita. (4) Kisah Quríani memiliki keistimewaan karena, melalui topik cerita, kisah dapat memuaskan pemikiran, seperti pemberian sugesti, keinginan, dan keantusiasan, perenungan dan pemikiran.

\section{Membekas dalam jiwa dan menarik perhatian}

Kelebihan kelima ini dapat membekas dalam jiwa dan menarik perhatian. Ketika memberikan pelajaran kepada para sahabat Rasulullah SAW seringkali menggunakan metode bercerita tentang kehidupan masa lalu. Metode ini dianggap akan lebih membekas dalam jiwa orang-orang yang mendengarkannya serta lebih menarik perhatian dan konsentrasi peserta didik (Ghuddah, tt.: 194). Interaksi kisah Qur’ani dan Nabawi dengan diri manusia dalam keutuhan realitasnya tercermin dalam pola terpenting yang hendak ditonjolkan oleh al-Qur`an kepada manusia di dunia dan hendak mengarahkan perhatian pada setiap pola yang selaras dengan kepentinganya.

\section{KEKURANGAN METODE BERCERITA}

Di samping kelebihan terdapat pula kelemahan yang dimiliki metode bercerita. Kelemahan ini sekaligus juga untuk dihindari oleh guru PAI dalam proses penggunaannya dan juga untuk diminimalisir hal tersebut dalam proses pembelajaran. Kekurangan metode bercerita ini dapat dilihat pada hal-hal berikut.

\section{Pemahaman peserta didik menjadi sulit ketika cerita itu telah terakumulasi oleh masalah lain}

Pada proses pembelajaran dengan menggunakan metode cerita seringkali cerita tersebut kurang konsisten dengan alur yang telah ditentukan. Cerita seringkali terakumulasi dengan masalah lain sesuai dengan pengalaman guru PAI dalam pemahaman cerita. Bahkan cerita yang disampaikan bias meluas ke masalah lain hingga substansi cerita semakin jauh dan waktu pun banyak terbuang. Akumulasi cerita bisa muncul dari aspek pemahaman dan latar belakang guru PAI tersebut dan ini tak jarang mempengaruhi cerita yang sedang disampaikan guru dalam proses pembelajaran. Cerita yang terakumulasi maksudnya adalah isi cerita yang sedang disampaikan kepada peserta didik tercampur dengan cerita lain yang tak berhubungan dan mempengaruhi substansi cerita yang sedang diajarkan.

Cerita yang terakumulasi akan memberikan dampak negatif bagi pemahaman peserta didik karena mereka akan sulit untuk mengambil intisari dari cerita tersebut. Bila hal ini terjadi, maka peserta didik pun akan sulit untuk memahami cerita yang disampaikan oleh guru PAI. Imbasnya tujuan pembelajaran yang telah ditetapkan sebelumnya akan jauh dari ketercapaian maksimal. Kesulitan pemahaman inilah kemudian yang perlu untuk diperhatikan oleh guru dalam proses penggunaan metode ini. Bahkan hal ini pulalah yang mesti dihindari oleh guru PAI dalam proses menunjang kualitas pembelajaran PAI tersebut. 


\section{Bersifat monolog dan menjenuhkan peserta didik}

Penggunaan metode bercerita dalam proses pembelajaran biasanya hanya menjadikan guru sebagai one man show dan aktif dalam menyampaikan cerita. Bersifat monolog menggambarkan bahwa hanya guru PAI saja yang dapat memberikan interaksi satu arah kepada peserta didik sementara peserta didik hanyalah pendengar setia. Peserta didik hanyalah menjadi pendengar setia yang tak boleh berisik dan sikap buruk lainnya karena mengganggu pada konsentrasi cerita. Bila penggunaan metode cerita yang dilangsungkan guru dalam proses pembelajaran kurang baik maka peserta didik akan merasa jenuh dan bosan.

Dapat ditegaskan di sini bahwa apabila guru PAI tidaklah seorang pencerita ulung atau pendongeng yang baik kemungkinan hal itu akan menjadi penghambat dalam menggunakan metode bercerita. Sebab guru dalam memberikan pembelajaran bersifat monolog maka dibutuhkan kemampuan guru dalam teknik-teknik menggunakan metode bercerita. Terkadang karena penggunaan metode bercerita yang bersifat monolog mengakibatkan peserta didik bosan hingga motivasi dan gairah belajar pun akan menurun.

\section{Sering terjadi ketidakselarasan isi cerita dengan konteks yang dimaksud sehingga pencapaian tujuan sulit diwujudkan}

Cerita memang dituntut untuk selalu konsisten dengan alur yang telah disusun oleh guru dalam pembelajaran. Isi cerita tak jarang kurang selaras dengan konteks yang mengakibatkan tujuan cerita pun sulit untuk dicapai. Maka dengan hal ini seorang guru PAI harus mempersiapkan secara signifikan alur cerita agar tetap berada pada jalurnya dan mencapai tujuan yang diharapkan. Guru PAI yang baik sejatinya dapat menselaraskan isi cerita dengan konteks yang dimaksud agar tujuan cerita tersebut dapat tercapai dengan maksimal.

\section{Waktu banyak terbuang bila cerita kurang tepat}

Penggunaan yang tidak tepat guna dalam metode bercerita akan menjadi penghalang kelancaran jalannya proses pembalajaran PAI sehingga banyak waktu dan tenaga terbuang sia-sia, tanpa hasil yang memuaskan. Oleh karena itu metode yang diterapkan dikatakan berhasil, jika mampu dipergunakan waktu secara efektif dan efisien untuk mencapai tujuan pembelajaran. Terkadang seorang guru PAI terlalu asyik bercerita yang berawal dari konteks yang sesungguhnya dalam silabus pembelajaran namun bila tidak terkontrol bisa merembet ke alur cerita kekinian yang jauh dari alur cerita awal.

Bercerita biasanya memang sangat asyik dilakukan oleh seorang guru PAI dan ini sangatlah lumrah dan terlihat sudah terbiasa. Semua kita sangat senang bercerita tak terkecuali juga guru PAI di sekolah, dan karena kebiasaan bercerita itu tak jarang alur cerita bergeser ke mana-mana. Dampaknya waktu pun akan tersita banyak dan terbuang sia-sia hanya untuk menceritakan selembar isi cerita. Hal inilah yang perlu untuk diantisipasi oleh guru PAI dalam menggunakan metode bercerita pada setiap pembelajaran yang dilangsungkan.

\section{DESAIN METODE BERCERITA}

Al-Qur`an dalam menyampaikan pesan-pesannya, selain menggunakan cara yang langsung, yaitu berbentukbentuk perintah dan larangan, banyak 
juga tuntutan tersebut disampaikan melalui cerita-cerita. Banyak pula surat yang dikhususkan untuk cerita semata, seperti surat Yusuf, al-Anbiya, alQoshas, dan surat Nuh. Ini menunjukkan cerita sangat besar pengaruhnya terhadap pendidikan. Cerita adalah metode yang paling ampuh dalam pendidikan, apalagi cerita tersebut dikemas dengan alur cerita yang baik dan ditambah dengan teknologi yang memadai, serta didukung dengan media televisi, VCD, dan media lainnya.

Disadari atau tidak, cerita dalam bentuk film kartun yang sering ditayangkan ditelevisi seperti Upin dan Ipin yang berpengaruh masuknya budaya Malaysia dan Islam ke dalam pribadi anak-anak yang menyukainya. Begitu juga film Sang Pencerah yang disadari atau tidak akan memberikan pendidikan agama Islam terhadap anakanak bahkan orang dewasa. Betapa tidak, kelakuan tokoh dalam sebuah film akan menjadi contoh yang akan ditiru penonton yang mengidolakannya. Begitu juga dengan film Ayat-Ayat Cinta yang sebagian orang berpendapat bahwa mengandung misi poligami, film Wanita Berkalung Sorban, yang mengkritik pandangan keliru tentang wanita, juga film Laskar Pelangi yang memuat semangat pendidikan. Semuanya adalah cerita yang disampaikan melalui media film.

Cerita-cerita dalam film tersebut, secara tidak sadar akan menggugah hati seseorang untuk menerima pesan yang ada didalamnya. Menurut Abudin Nata, Islam menyadari sifat alamiah manusia untuk menyenangi cerita yang pengaruhnya besar terhadap perasaan. Oleh karenanya dijadikan sebagai salah satu teknik pendidikan (Nata, 2001: 97). Terkait dengan hal itu, diperlukan sebuah desain metode cerita dalam pembelajaran pendidikan agama Islam agar guru dapat dengan mudah menerapkannya hingga pembelajarannya menarik dan sampai pada tujuan maksimal. Desain metode cerita itu dapat dilihat dalam paparan berikut:

\section{Gambar 1.}

Desain Metode Bercerita

dalam Pembelajaran Pendidikan Agama Islam

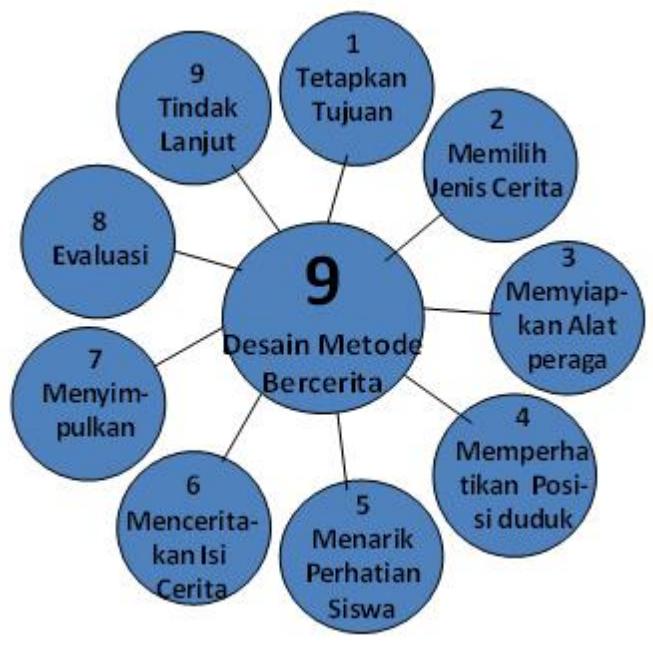

\section{Menetapkan Tujuan}

Langkah pertama adalah menetapkan tujuan dari metode bercerita. Agar proses pendidikan dapat terlaksana dengan baik dan mencapai sasaran, maka salah satu faktor penting yang harus diperhatikan adalah menentukan tujuan dari pembelajaran tersebut. Hal ini pulalah yang menjadikan bahwa setiap kegiatan harus dituntut menetapkan tujuan yang jelas demikian juga halnya dalam metode bercerita pada setiap kegiatan pembelajaran pendidikan agama Islam. Penetapan tujuan akan menjadi semacam pelurus langkah dalam meneruskan perjalanan dalam penggunaan metode bercerita.

Penetapan tujuan dalam metode bercerita tidak lepas dari tujuan pembelajaran yang diawali dari indikator pembelajaran yang telah ditetapkan sebelumnya. Indikator yang telah ada sekaligus menjadi seleksi bagi seorang guru PAI atau calon guru 
lainnya dalam pemelihan metode pembelajaran yang tepat untuk diterapkan pada saat proses pembelajaran PAI. Oleh karena itu siapapun yang akan mengajarkan materi PAI haruslah berhati-hati dan teliti dalam memilah indikator yang ada. Penetapan tujuan dalam metode ini sudah menjadi hal lumrah yang harus ditetapkan oleh guru PAI dalam setiap jenis metode yang dipergunakan.

\section{Memilih Jenis Cerita}

Guru PAI hendaknya memilih jenis cerita yang sangat ia kuasai. Seorang guru PAI tetap dituntut untuk menguasai penceritaan berbagai jenis dongeng tentunya dengan latihan yang dilakukan terus-menerus. Jenis cerita terkadang memang guru PAI yang menentukan, namun di sisi lain bila memang indikator pembelajaran PAI menceritakan kisah Nabi Ibrahim a,s, misalnya maka tidak dapat tidak seorang guru PAI harus menyesuaikan dengan indikator tersebut hingga tidak ada alasan lain untuk memilih jenis cerita yang sesuai. Di sini berarti terdapat dua hal penting dalam jenis cerita ini yaitu cerita di mana indikator pembelajarannya telah ditentukan jenis ceritanya, dan cerita di mana dalam indikator tidak disebutkan jenis ceritanya.

Ada faktor lain yang dapat membantu dalam pemilihan cerita, yaitu situasi dan kondisi peserta didik. Situasi dan kondisi peserta didik sangatlah penting untuk diperhartikan dalam hal memilih jenis cerita yang akan diajarkan. Kejelian guru PAI dalam memperhatikan situasi dan kondisi peserta didik tersebut dapat berdampak pada kesuksesna dalam pembelajaran PAI yang sedang dilangsungkan. Sebagai catatan bagi guru, harus diingat bahwa dalam penyampaian cerita yang lucu dan sedih, ia harus bercerita dengan menggunakan cara yang tepat agar murid tidak salah mengapresiasikan.

\section{Menyiapkan Alat Peraga}

Alat peraga dalam bercerita sangat penting untuk dipersiapkan. Sebab bercerita itu dapat dibagi menjadi dua yaitu bercerita tanpa menggunakan alat peraga dan bercerita dengan menggunakan alat peraga. Di saat bercerita tanpa menggunakan alat peraga tentu tidak ada yang harus dipersiapkan terkait dengan alat peraga, hanya yang perlu dipersiapkan adalah suara yang baik dan stamina yang cukup. Sedang bercerita dengan menggunakan alat peraga, inilah yang harus dipersiapkan alat peranganya. Guru PAI yang baik dalam proses pembelajaran apapun sejatinya harus menggunakan alat peraga, demikian juga halnya dalam penggunaan metode bercerita.

Alat peraga yang perlu dipersiapkan dalam metode bercerita adalah disesuaikan dengan jenis cerita yang akan diajarkan. Penggunaan alat peraga dapat mempengaruhi ketercapaian tujuan pembelajaran PAI yang sedang dilangsungkan. Secara umum alat peraga yang perlu dipersiapkan guru PAI dalam mensukseskan pembelajarannya adalah; papan planel, buku cerita, boneka, gambar berseri, lotto, poster, dan lainnya. Semua ini dipilih oleh guru PAI yang sesuai dengan jenis certa yang akan diajarkan.

\section{Memperhatikan Posisi Duduk Peserta didik}

Langkah ketiga dalam menggunakan metode bercerita adalah perhatikan posisi duduk peserta didik. Ketika bercerita, yang diharapkan 
adalah perhatian para peserta didik dengan sepenuh hati dan pikiran mereka. Oleh karena itu guru harus dapat menguasai cerita yang disampaikan dengan baik. Ketika penceritaan berlangsung, para peserta didik hendaknya diposisikan secara khusus, tidak seperti waktu mereka belajar menulis dan membaca. Hubungan guru dengan para peserta didiknya dalam bercerita hendaknya seperti hubungan tuan rumah dengan tamuanya. Oleh karena itu, sangatlah dianjurkan bila posisi duduk para peserta didik dekat dengan guru. Posisi duduk yang baik bagi para peserta didik dalam mendengarkan cerita adalah berkumpul mengelilingi guru dengan posisi setengah lingkaran atau mendekati setengah lingkaran. Guru harus dapat memastikan bahwa para peserta didik merasa bebas jiwanya.Untuk dapat mengundang perhatian mereka, sebaliknya guru tidak langsung duduk ketika mulai bercerita, tetapi memulainya dengan berdiri, lalu pada menit-menit selanjutnya secara perlahan-lahan ia bersiap untuk duduk pada saat menyampaikan pembukaan cerita, kemudian setelah itu barulah ia duduk.

Posisi duduk peserta didik ini dianjurkan bahwa seluruh mereka dapat dengan jelas melihat guru bergerak ke bagian kiri, kanan, dan tengah kelas. Hal ini dimaksudkan untuk menjadikan cerita yang disampaikan dapat didengar dan diperhatikan dengan baik oleh semua peserta didik. Di samping juga untuk melihat guru PAI karena gerakan guru PAI dapat mempengaruhi perhatian dan gairah para peserta didik dalam mendengar cerita. Oleh karena itu sebelum cerita dimulai maka seorang guru PAI harus memperhatikan sampai pada kursi peserta didik sebagai tempat duduk mereka apakah bermasalah atau sudah nyaman bagi mereka.

\section{Menarik Perhatian Peserta didik dalam Penyimakan}

Langkah keempat dalam metode bercerita adalah guru PAI memperhatikan peserta didik dalam penyimakan agar peserta didik dapat memperhatikan cerita. Penyimakan adalah pemahaman peserta didik secara penuh terhadap apa yang didengarnya dari kisah-kisah yang disampaikan oleh guru. Dalam ilmu jiwa, setiap kata atau ungkapan yang didengar atau dibaca oleh manusia akan memberi pengaruh dalam jiwanya, meliputi gambaran, arti, dan peristiwa seperti yang ia ingat dalam perjalanan hidupnya. Pengalaman setiap individu dalam memaknai gambaran, arti, dan peristiwa jelas berbeda sesuai kecerdasan masing-masing.

Anak-anak pada usia dini sulit menahan perhatiannya dalam waktu yang lama. Mereka juga tidak akan bertahan lama duduk dalam satu tempat. Untuk itu, kami ingatkan agar guru PAI selalu memperhatikan hal-hal berikut: (1) Perhatian peserta didik timbul biasanya karena pengaruh cerita, rangkaian peristiwa, dan cara penyampaiannya. Keberlangsungan perhatian itu bergantung pada keinginan si peserta didik sendiri. (2) Sulit untuk membuat peserta didik tetap berada di satu tempat duduk sepanjang cerita berlangsung. Jika para peserta didik mulai terlihat bosan dan banyak bergerak maka guru harus mulai mencari penyebabnya. (3) Berbagai peristiwa dalam cerita haruslah merupakan satu rangkaian yang tidak terputus agar menjadi satu cerita yang utuh. (4) Dalam proses penyimakan, para peserta didik membayangkan diri mereka bermain 
bersama para tokoh dalam cerita dengan peran yang berbeda-beda. Mereka terlihat mulai khayalannya mengikuti jalannya cerita. (5) Di pertengahan penyimakan itu, para peserta didikjuga mengikuti perasaan guru yang bercerita dengan perasaan mereka sendiri, baik ketika sedih, gembira, atau marah. (6) Setelah mendengar cerita, para peserta didik diharapkan dapat menceritakan kembali sebagian atau seluruhnya dari cerita yang telah didengarnya, dengan menggunakan salah satu metode pengungkapan. (7) Cerita biasanya tidak membutuhkan peralatan menulis. Untuk itu, jika memungkinkan, guru bisa mengajak murid keluar kelas dan bercerita di udara bebas.

\section{Menceritakan Isi Cerita dengan Lengkap}

Pada tahap ini, guru pendidikan agama Islam harus dengan jelas menceritakan cerita yang telah disusun dengan baik agar peserta didik dapat mengikuti secara maksimal. Sebuah cerita atau dongeng anak umumnya menyajikan alur dan tutur bahasa yang ringan dan menyenangkan, sehingga mudah dipahami anak. Gaya bercerita, intonasi, ekspresi dan pelafalan yang jelas merupakan bagian penting dalam bercerita yang dapat memudahkan penyerapan dan pemahaman anak akan nilai yang terkandung dalam cerita atau dongeng tersebut, serta berkembangnya imajinasi anak. Efek fun dan learning yang terkandung dalam sebuah cerita atau dongeng merupakan energi, gambaran kekuatan sebuah cerita. Di samping itu, cara bercerita kita sebagai guru tentu lebih mengentalkan efek tersebut agar lebih disukai anak-anak. Bagaimana kita bercerita dan kekuatan apa yang terkandung dalam sebuah cerita hingga bisa memberikan manfaat bagi kepribadian anak? Cerita yang dilangsungkan haruslah dengan tenang, dengan dengan teknik sebagai berikut: (1) Memberikan lebih jelas mengenai seluruh rangkaian peristiwa dalam cerita; (2) Menceritakan jumlah tokoh dalam cerita dan membedakan masingmasing karakternya; (3) mengetahui berbagai emosi yang ada dalam cerita, seperti sedih, gembira, marah, kasihan, heran, lucu, dan sebagainya.

Adapun yang sangat memegang peranan dalam jalannya cerita adalah tokoh dalam cerita itu sendiri. Tokoh yang dimaksud adalah setiap orang atau binatang yang memainkan peran dalam cerita. Disini guru pendidikan agama Islam harus memperhatikan kapasitas setiap tokoh, karena masing-masing mempunyai peran tersendiri dalam cerita. Guru menggolongkan tokoh ini dalam tiga tingkatan: (1) tokoh utama; tokoh yang memiliki keistimewaan dan peran khusus dalam cerita; (2) tokoh pembantu, tokoh yang memiliki peran biasa yakni sebagai bagian dari tugas keseharian tanpa ada warna atau sif at khusus,; (3) tokoh figuran; tokoh yang hanya muncul pada saat- saat ertentu. Biasanya bukan berupa individu melainan kelompok atau golongan. Guru hendaknya membaca cerita kedua kalinya untuk mempelajari sif at para tokoh dan mengetahui karakter serta keistimewaan masing-masing.

Dalam mempelajari karakter tokoh, termasuk juga penguasaan terhadap suara-suara khas yang dimilikinya. Adapun bentuk emosi dalam cerita adalah keadaan yang tampak dalam cerita. Pada pembacaan kedua ini guru hendaknya menulis di pinggir buku atau dalam catatan kecil, setiap ungkapan yang menyiratkan bentuk emosi yang sesuai. Memahami dengan baik berbagai tokoh yang berbeda dalam cerita, karakter setiap tokoh, dan bagaimana cara 
menirukannya dengan baik. Mempelajari dengan baik berbagai tokoh yangberbeda dalam cerita, karakter setiap tokoh, dan bagaimana cara menirukannya dengan baik.Guru juga mengetahui berbagai keadaan emosi dalam cerita dan harus mampu menggambarkannya sehingga dapat membekas di hat i para peserta didik.

Guru membaca cerita untuk ketiga kalinya dengan suara keras seraya membayangkan seolah-olah iaberada di dalam kelas dan para peserta didik mengelilinginya. Guru dapat menirukan berbagai macam suara binatang yang disebutkan dalam cerita sehingga ketika mendengar tiruan suara tersebut para peserta didik langsung dapat mengetahui bentuk binatangnya. Memperhitungkan hasil setelah cerita disampaikan dan dengan cara apa para peserta didik mengungkap kembali cerita. Mempersiapkan media yang dibutuhkan untuk ditampilkan ketika cerita berlangsung. Kita tidak mengharapkan banyak biaya dan tenaga yang dikeluarkan daam pengadaan media tersebut. Cukup dengan media yang sederhana dan mudah didapat. Seperti tongkat untuk menggambarkan janggut yang putih. Atau batu bata dan kerikil yang akan membantunya dalam menceritakan lima ekor ayam dalam cerita Ismail dan Lima Ekor Ayam. Memikirkan hasil setelah cerita disampaikan. Cara apa yang akan digunakan dalam penyampaian cerita, lalu mempelajarinya dan mempersiapkan apa yang dibutuhkan seperti pertanyaan atau media lainnya. Menuliskan hal-hal penting dalam cerita pada catatan persiapan pelaj ar an at au dalam sebuah catatan khusus. Dalam menggunakan metode bercerita ini ada beberapa teknik yang harus diperhatikan, yaitu:

\section{Menggunakan gaya bahasa yang baik dan mudah dimengerti peserta didik}

Dalam proses bercerita, menggunakan bahasa yang baik dan mudah, memiliki gaya bahasa yang sesuai bagi guru. Ia bisa saja menambah atau mengurangi ungkapan yang dirasanya cukup baik agar para peserta didik lebih mudah memahami jalannya cerita. Bahasa dal am bercerita hendaknya menggunakan gaya bahasa yang lebih tinggi dari gaya bahasa peserta didik sehari-hari tetapi lebih ringan dibandingkan gaya bahasa cerita dalam buku.

\section{Intonasi bercerita}

Intonasi guru dalam bercerita sangatlah penting dalam sebuah cerita di waktu mengajar. Pada permulaan cerit a guru hendaknya memulainya dengan suara tenang. Kemudian mengeraskannya sedikit demi sedikit. Perubahan naik-turunnya cerita harus sesuai dengan peristiwa dalam cerita. Ketika guru sampai pada puncak konflik ia harus menyampaikannya dengan suara ditekan dengan maksud menarik perhatian para peserta didik. Juga akan memberikan gambaran yang membuat mereka berpikir untuk menemukan klimaksnya.

\section{Membuat puncak konflik}

Puncak konflik ini dapat dilihat dari isi cerita dan ini memang harus betulbetul diperhatikan oleh guru PAI. Puncak konflik ini harus dapat digambarkan oleh guru PAI dengan suara, intonasi, dan mimik ekspresi guru PAI yang menunjukkan bahwa cerita tersebut memang ada konflik. Konflik dapat diekspresikan guru PAI dengan suara keras, gerakan yang menunjukkan ada konflik, tatapan yang menggambarkan ada konflik, dan 
lainnya. Puncuk konflik ini mengambarkan bahwa cerita yang disampaikan sedang memasuki tahap penting dari sebuah cerita hingga memang perlu untuk disimak dan diperhatikan oleh seluruh peserta didik.

\section{Membuat rangkaian peristiwa}

Saat menggunakan metode bercerita seorang guru PAI harus membuat rangkaian peristiwa yang terdapat dalam isi cerita. Rangkaian peristiwa tersebut dapat berupa urutan-urutan penting peristiwa dari cerita yang akan disampaikan pada peserta didik. Rangkaian peristiwa yang telah dicatat atau dipersiapkan dapat mempermudah guru PAI untuk menggunakan metode bercerita sekaligus menghindari akumulasi cerita yang sedang dilakukan dalam pembelajaran PAI.

\section{Membuat Klimaks Cerita}

Klimaks cerita adalah puncak dari cerita yang disampaikan di mana seluruh konflik atau persoalanpersoalan telah mencapai babak tertinggi dari sebuah sebuah cerita. Klimaks cerita ini perlu dibuat oleh guru PAI untuk menggiring peserta didik betul-betul terlibat konflik dan sampai pada puncuk tertinggi dari emosional peserta didik.

\section{Pemunculan Tokoh-tokoh}

Ketika mempersiapkan cerita, seorang guru harus mempelajari terlebih dahulu tokoh-tokohnya, agar dapat memunculkannya secara hidup di depan para peserta didik. Untuk itu, diharapkan guru dapat menjelaskan peristiwanya dengan jelas tanpa gemetar atau ragu-ragu. Ungkapan bisa disampaikan dengan disertai gerakan.
Dalam bercerita juga harus dapat menggambarkan setiap tokoh dengan gambaran yang sesungguhnya, dan memperlihatkan karakternya seperti dalam cerita.

\section{Penampakan emosi}

Saat bercerita guru harus dapat menampakkan keadaan jiwa dan emosi para tokohnya dengan memberi gambaran kepada pendengar bahwa seolah-olah hal itu adalah emosi si gurusendiri. Jika situasinya menunjukkan rasa kasihan, protes, marah atau mengejek, maka intonasi dan kerut wajah harus menunjukkan hal tersebut. Ekspresikan ungkapan emosi dalam cerita, seperti marah, sakit, terkejut, bahagia, gembira atau sedih agar anak mengenal dan memahami bentuk-bentuk emosi. Bila perlu sertakan benda-benda tambahan seperti boneka, bunga atau benda lain yang tidak membahayakan.

\section{Peniruan Suara}

Dalam penggunaan metode bercerita, peniruan suara-suara yang mirip dengan tokoh yang sedang diceritakan sangat menarik bagi para peserta didik. Sebab hal itu dapat menumbuhkan gairah dan simpati peserta didik terhadap certa yang sedang diajarkan. Sebagian orang ada yang mampu meniru suara- suara binatang dan benda tertentu. Seharusnya guru PAI tidak perlu merasa rendah dengan peniruan suara ini, karena pekerjaan mengajar adalah mulia.

\section{Penguasaan terhadap peserta didik yang tidak serius}

Perhatian peserta didik di tengah cerita haruslah dibangkitkan sehingga 
mereka bisa mendengarkan cerita dengan senang hati dan berkesan. Apabila guru melihat para peserta didik mulai bosan, jenuh, dan banyak bercanda, maka ia harus mencari penyebabnya. Ketika proses bercerita berlangsung, guru mungkin menemukan salah seorang murid yang mengabaikan cerita dan menyepelekannya. Dalam hal ini guru tidak boleh memotong penyampaian cerita untuk memperingatkan anak tersebut, tetapi dapat dengan menghampirinya, menarik tangannya dan mendudukkan kembali peserta didik tersebut di tempat duduknya, atau membiarkannya.

\section{Menghindari ucapan spontan}

Guru PAI dalam menggunakan metode bercerita acapkali mengucapkan ungkapan spontan setiap kali menceritakan suatu peristiwa. Ucapan spontan seringkali tak disadari dengan baik oleh guru PAI dan ia datang tanpa sebab. Kebiasaan ini tidak baik karena bisa memutuskan rangkaian peristiwa dalam cerita. Apabila rangkaian peristiwa talah terputus maka konsentrasi peserta didik dalam mendengarkan cerita yang disampaikan oleh guru PAI akan bias dan bahkan memunculkan pemahaman yang kabur. Ucapan spontan dapat berupa kata-kata yang biasa diucapkan oleh guru PAI dalam kesehariannya dan itu di luar konteks cerita yang sedang diceritakan.

\section{Ungkapan ulang peserta didik setelah penceritaan}

Salah satu tujuan bercerita pada tingkat pertama adalah mengukur kemampuan peserta didik untuk mengungkapkan ide dan apa-apa yang diketahuinya dari cerita. Pengungkapan cerita bisa dilakukan secara lisan saja, atau dengan lisan dan gerakan tubuh serta ekpresi jiwa, yaitu memeragakan sambil bercerita. Hal yang terpenting yang harus kita perhatikan dalam belajar bahasa ialah pengungkapan dengan lisan atau disertai peragaan. Sebaiknya, kita tidak menggunakan pengungkapan non lisan, karena pertama, pengungkapan non-lisan lebih sulit dimengerti para peserta didik daripada pengungkapan secara lisan; kedua, kita bermaksud memperbaiki bahasa dan gaya bahasa para peserta didik. Oleh karena itu, ungkapan lisan lebih baik dari ungkapan non-lisan. Di sinilah seorang guru PAI harus meminta peserta didik untuk mengulang kembali isi cerita yang dikuasai oleh siwa.

\section{Peragaan}

Peragaan adalah mengungkapkan ide dengan bahasa, ger akan, dan per asaan. Dalam bahasan metode bercerita telah kita sebutkan bahwa guru harus menjaga bahasa cerita, suara, dan intonasinya sehingga sesuai dengan ide yang disampaikan. Guru memerlukan beberapa sarana di dalam kelas untuk membuat peragaan yang mengasyikan dan menyenangkan. Di masa sekarang, bercerita atau mendongeng memang merupakan hal yang jarang dilakukan. Peran dan fungsinya sudah banyak tergantikan oleh tayangan televisi dan bermain game di komputer. Zaman memang dinamis, meski tidak selalu menimbulkan dampak yang harmonis. Terlepas dari semua itu, cerita atau dongeng memiliki kekuatan, fungsi dan manfaat sebagai media komunikasi, sekaligus metode dalam membangun kepribadian anak. Cara bercerita atau mendongeng merupakan unsur yang membuat dongeng atau cerita itu menarik dan disukai anak-anak. Hal ini 
mengingatkan saya akan pengalaman saya sendiri di masa kecil, saya begitu menyukai dongeng, cerita, dan mengagumi seorang tokoh pendongeng.

\section{Bercerita tanpa alat peraga}

Bercerita yang dilangsungkan oleh guru dalam pembelajaran PAI dapat dilakukan dengan tidak menggunakan alat peraga. Tidak menggunakan alat peraga berarti hanya memanfaatkan lisan atau suara yang dimiliki serta gerak tubuh yang baik.

\section{Bercerita dengan menggunakan alat peraga.}

Jenis bercerita dengan

menggunakan alat peraga adalah; Pertama, bercerita dengan menggunakan gambar; Kedua, membaca langsung dari buku cerita. Teknik ini membacakan langsung dari buku cerita yang dimiliki guru sesuai dengan anak terutama dikaitkan dengan pesan-pesan yang tersirat dalam cerita. Ketiga, bercerita menggunakan ilustrasi gambar dari buku. Teknik ini menggunakan ilustrasi gambar dari buku yang dipilih guru, harus menarik, lucu, sehingga anak dapat mendengarkan dan memusatkan perhatian lebih besar daripada buku cerita. Ilustrasi gambar yang digunakan sebaiknya cukup besar dilihat oleh anak dan berwarna serta urut dalam menggambarkan jalan cerita yang disampaikan. Keempat, bercerita dengan menggunakan papan flannel. Teknik ini menekankan pada urutan cerita serta karakter tokoh yang terbuat dari papan flannel yang berwarna netral. Gambar tokoh-tokoh mewakili perwatakan tokoh cerita yang digunting dengan pola kertas dan ditempelkan pada kain flannel. Kelima, bercerita dengan menggunakan boneka.
Pemilihan cerita dan boneka tergantung pada usia dan pengalaman anak. Boneka yang digunakan mewakili tokoh cerita yang akan disampaikan.

\section{Menyimpulkan Isi Cerita}

Isi dari cerita yang telah disampaikan sebelumnya secara bersama-sama guru PAI dengan peserta didik membuat kesimpulan. Kesimpulan yang diambil secara bersama-sama dimaksudkan untuk memberikan kesempatan kepada peserta didik memberikan kesimpulan terhadap materi yang dipelajari. Kesimpulan pembelajaran ini sangat penting artinya bagi peserta didik untuk memberikan pemahaman yang sama terhadap ceirta yang disampaikan sekaligus memberikan aspek-aspek penting yang harus diingat dan diteladani dalam kehidupan sehari-hari. Penyimpulan isi cerita ini dapat dilakukan dengan; guru PAI meminta satu atau dua orang peserta didik untuk memberikan pendapat apa yang diketahuinya sesuai dengan indikator yang ditetapkan; setelah itu guru merangkum pendapat-pendapat peserta didik tersebut dan meramunya menjadi sebuah kesimpulan dari cerita yang disampaikan.

\section{Mengadakan Evaluasi}

Setelah secara bersama-sama menyimpulkan isi pembelajaran cerita maka tahap selanjutnya adalah mengevaluasi hasil pembelajaran yang diketahui oleh peserta didik. Evaluasi pembelajaran ini dimaksudkan untuk mengetahui tingkat penguasaan bahan pembelajaran peserta didik dengan menggunakan metode bercerita tersebut. Evaluasi pembelajaran ini dapat dilakukan dengan dua hal yaitu; evaluasi dengan menggunakan secara 
lisan; dan evaluasi dengan menggunakan secara tertulis. Evaluasi ini merupakan bagian dari terpenting dari perjalanan seorang guru dalam menwujudkan diri menjadi guru profesional. Bahkan salah satu ciri seorang guru professional adalah di mana guru tersebut selalu menggunakan evaluasi dalam setiap pembelajarannya. Guru pendidikan agama Islam harus mampu melakukan evaluasi sebagai bagian untuk memberikan umpan balik terhadap hasil cerita yang telah dilaksanakan. Evaluasi diperlukan untuk mengetahui tingkat pemahaman dan penguasaan peserta didik terhadap materi yang diajarkan melalui metode cerita tersebut. Di samping itu juga evaluasi diperlukan untuk memberikan umpan balik bagi guru terhadap efektifitas dan tingkat keberhasilan penggunaan metode yang dilangsungkan.

Hal ini perlu dilakukan agar guru pendidikan agama Islam dapat melakukan perbaikan terhadap penggunaan metode diskusi yang dilakukan. Hal inilah yang sering diabaikan oleh para guru pendidikan agama Islam saat ini. Mengabaikan evaluasi terhadap penggunaan metode yang dilakukan dan seringkali evaluasi ini hanya bagi tingkat penguasaan peserta didik terhadap materi pelajaran. Pola ini sesungguhnya sudah haru diperbaiki agar pembalajaran pendidikan agama Islam dari ke hari menunjukkan kualitas maksimal.

\section{Tindak Lanjut}

Setelah guru PAI mengadakan evaluasi terhadap dua aspek penting di atas yaitu evaluasi terhadap penguasaan materi peserta didik dan evaluasi terhadap keberhasilan penggunaan metode maka langkah berikatunya adalah melakukan tindak lanjut. Tindak lanjut ini dapat dilakukan melalui hasil evaluasi dari kedua hal di atas. Bila memang ada peserta didik yang kurang dalam penguasaan materi pelajaran maka guru PAI harus mencari penyebab dan itu harus dieksekusi atau dilakukan perbaikan dengan cepat untuk pembelajaran berikutnya dengan metode bercerita tersebut.

Tindak lanjut ini sangat penting dalam sebuah pembelajaran, sebab tak jarang hal ini diabaikan oleh kebanyakan guru PAI. Evaluasi yang telah dilakukan terkadang hanya tinggal di situ, tak ada tindak lanjut nyata sebagai perbaikan terhadap kekurangan dan kelebihan yang telah diperoleh dari keseluruhan kegiatan pembelajaran. Tindak lanjut diperlukan sebagai bagian dari usaha perbaikan bagi seluruh kegiatan pembelajaran yang dilakukan sekaligus juga untuk kegiatan pendidikan secara umum.

\section{SIMPULAN}

Metode bercerita dalam pembelajaran PAI adalah cara penyajian materi pembelajaran secara lisan dengan menceritakan peristiwa sejarah hidup manusia di masa lampau yang menyangkut ketaatan untuk diteladani atau kemungkaran untuk ditinggalkan yang bersumber dari al-Qur'an dan alHadits menggunakan alat peraga pendidikan untuk meningkatkan pemahaman dan pembinaan kepribadian peserta didik.

Cerita mempunyai daya tarik yang dapat menyentuh perasaan anak. Sebab cerita itu pula kenyataannya dapat merajut hati manusia dan dapat mempengaruhi perasaan dan pula kehidupan mereka. Cerita tentang kisah-kisah yang mengandung hikmah sangat efektif untuk menarik perhatian anak dan merangsang otaknya agar 
bekerja dengan baik, bahkan metode ini dianggap baik dalam merangsang pola pikir anak. Karena dengan mendengar cerita, pemikiran dan emosional anak terangsang sehingga tertarik menyerap pesan yang disampaikan tanpa dipaksakan. Cara seperti ini telah dicontohkan oleh Rasulullah SAW sejak dahulu, "beliau sering bercerita tentang kisah-kisah kaum terdahulu kepada sahabatnya dengan tujuan dapat mengambil hikmah dan pelajaran".

Allah SWT dalam memberikan pelajaran pada manusia banyak menggunakan metode bercerita yakni menceritakan kisah-kisah yang baik untuk diteladani dan menceritakan kisah-kisah yang buruk untuk dihindarkan. Hal ini misalnya dapat dilihat pada sebuah ayat yang menggambarkan nilai pedagogis dalam sejarah diungkapkan oleh Allah SWT dan ini sekaligus sebagai landasan metode bercerita dalam al-Qur'an, sebagai berikut:
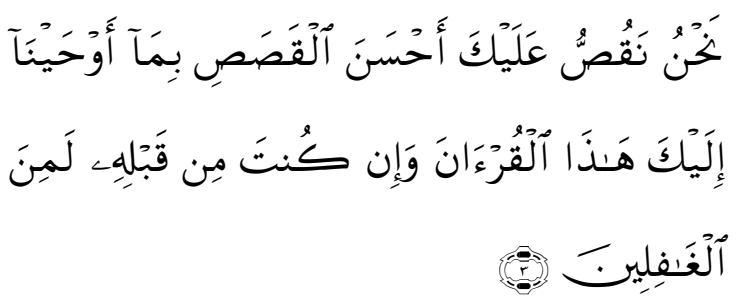

Artinya: "Kami menceritakan kepadamu kisah yang paling baik dengan mewahyukan Al Quran ini kepadamu, dan sesungguhnya kamu sebelum (kami mewahyukan)nya adalah termasuk orang-orang yang belum mengetahui". (QS. Yusuf, 12: 3).

Kata yang menggambarkan secara langsung pada metode bercerita adalah "naqushshu" yang berarti Kami menceritakan. Naqushshu berasal dari kata qashsha-yaqushshu bentuk fi'il madhi dan fi'il mudhari', artinya menceritakan. Dalam ayat di atas tampak secara jelas bahwa terdapat guru yang mengajarkan yaitu Allah SWT sendiri sebagai sebagai guru memberikan isi cerita yang terbaik "ahsanal qashash" sebagai materi pembelajaran. Materi pembelajaran yang diajarkan dengan metode bercerita itu adalah kisah yang paling baik yaitu yang terdapat dalam wahyu Allah SWT al-Qur'an. Al-qashash menurut Quraish Shihab adalah bentuk jamak dari qishshah/kisah. Ia terambil dari kata qashsha yang pada mulanya berarti mengikuti jejak. Kisah adalah upaya mengikuti jejak peristiwa yang benar-benar terjadi atau imajinatif sesuai dengan urutan kejadiannya dan dengan jalan menceritakannya satu episode atau episode demi episode.

Ahsanal qashash dapat dimaknai sebagai materi pembelajaran yang diajarkan melalui metode bercerita. Ahsanal qashash adalah kisah yang paling baik. Ahsanal qashash pada ayat ini digambarkan dalam buku Syamil alQur'an Miracle The Reference adalah kisah Nabi Yusuf as. Kisah Nabi Yusuf as adalah sebaik-baik kisah dalam perjalanan sejarah hidup manusia. Nabi Yusuf as. (dikenal dalam Bibel sebagai Josef) adalah salah seorang nabi yang hidupnya banyak diceritakan dalam alQur'an. Nyaris seluruh bagian surah Yusuf, salah satu yang terpanjang di dalam al-Qur'an, mengisahkan kehidupannya dan keluarganya. Pada awal surah ini, Allah mengungkapkan bahwa kisah hidupnya mengandung tanda-tanda bukti-bukti, dan hikmah yang penting. "Sesungguhnya, ada tanda-tanda kekuasaan Allah pada (kisah) Yusuf dan saudara-saudaranya bagi orang-orang yang bertanya" (QS. Yusuf, 12: 7). Sebagaimana halnya dengan nabi-nabi lainnya, orang-orang yang beriman yang membaca kisah Nabi Yusuf as. akan menemukan banyak hal yang menenteramkan dan mendapatkan banyak pelajaran.

Situasi penggunaan metode pembelajaran PAI sangat penting untuk 
diperhatikan oleh guru atau calon guru PAI di sekolah. Hal dibutuhkan untuk menjadikan metode bercerita yang digunakan tepat sasaran dan dapat menjadikan materi pembelajaran PAI diterima dan dipahami dengan baik oleh peserta didik. Terdapat beberapaa situasi penggunaan metode bercerita dalam pembelajaran PAI, yaitu: Pertama, di saat mendidikan keteladanan. Anda sebagai seorang guru PAI atau calon guru PAI di sekolah harus jeli melihat materi yang akan diajarkan pada peserta didik. Apabila materi yang diajarkan memang untuk menggiring peserta didik pada penguasaan akhlak dan moral maka metode bercerita sangat tepat untuk digunakan. Sebab dengan menceritakan sebuah kisah yang sesuai dengan silabus pembelajaran PAI biasanya peserta didik lebih terikat dan mengikuti ide cerita sembari membandingkan dengan dirinya hari ini. Bila demikian halnya maka keteladanan yang ada dalam cerita diharapkan dapat diresapi oleh peserta didik dalam kehidupan sehari-hari.

Kedua, di saat ingin menarik perhatian dan merangsang otak anak. Cerita tentang kisah-kisah yang mengandung hikmah sangat efektif untuk menarik perhatian anak dan merangsang otaknya agar bekerja dengan baik, bahkan metode ini dianggap yang terbaik dari cara-cara yang lain dalam mempengaruhi pola bantu anak. Karena dengan mendengarkan cerita, anak didik akan merasakan senang sekaligus menyerap nilai-nilai pendidikan agama Islam tanpa merasa dipaksakan. Ketiga, di saat untuk menanamkan nilai akhlak dan emosional. Rasulullah SAW menggunakan metode cerita ini, menurut Yusuf al-Qardawi, dalam menjelaskan nilai-nilai dan maknamakna tertentu serta menegaskannya, seperti penjelasan tentang nilai-nilai keikhlasan dalam menyelamatkan manusia dari kehancuran, yang tersebut dalam kisah tiga orang penghuni syurga, yaitu orang buta, cacat, dan berpenyakit. Keempat, pada anak usia pra-sekolah. Pada anak usia prasekolah, metode ini sungguh baik diterapkan karena dengan cerita anak dapat memperhatikan dan melibatkan diri dengan cerita-cerita yang didengarkan dari guru PAI walaupun kemampuan untuk mengungkapkan isi cerita belum sempurna. Orang tua dapat memberikan cerita mulai dari hal-hal yang sederhana.

Kelima, pada peserta didik yang memiliki kecerdasan verbal-linguistik. Peserta didik yang memiliki kecerdasan verbal linguistik cenderung memiliki kemampuan retoris bahasa atau kemampuan untuk meyakinkan orang lain dari serangkaian tindakan, potensi dalam mengingat bahasa, atau kemampuan untuk mengingat bahasa dalam mengingat daftar atau proses; kapasistas bahasa untuk menerangkan konsep dan nilai metofora dalam melakukannya, dan penggunaan bahasa untuk merefleksikan bahasa atau menggunakannya dalam analisis "metalinguistik".

Metode bercerita memiliki kelebihan dibanding dengan metode lainnya dalam proses pembelajaran pendidikan agama Islam. Kelebihan metode bercerita ini memiliki kelebihan dalam pembelajaran PAI, yaitu; dapat mengaktifkan dan membangkitkan semangat peserta didik; mengarahkan emosi menyatu pada kesimpulan; memikat; mempengaruhi emosi; dan membekas dalam jiwa dan menarik perhatian. Di samping kelebihan terdapat pula kelemahan yang dimiliki metode bercerita. Kelemahan ini sekaligus juga untuk dihindari oleh guru PAI dalam proses penggunaannya 
dan juga untuk diminimalisir hal tersebut dalam proses pembelajaran. Adapun kekurangan metode bercerita ini dapat dilihat pada hal-hal berikut, yaitu; Pemahaman peserta didik menjadi sulit ketika cerita itu telah terakumulasi oleh masalah lain; Bersifat monolog dan menjenuhkan peserta didik; Sering terjadi ketidakselarasan isi cerita dengan konteks yang dimaksud sehingga pencapaian tujuan sulit diwujudkan; dan waktu banyak terbuang bila cerita kurang tepat.

Metode bercerita memiliki lengkahlangkah yang sangat urgen diketahui dan dimiliki oleh sesorang yang akan menjadi calon guru atau yang sudah menjadi guru pada hari ini. Langkahlangkah metode bercerita tersebut adalah; Pertama, menetapkan tujuan. Langkah Agar proses pendidikan dapat terlaksana dengan baik dan mencapai sasaran, maka salah satu faktor penting yang harus diperhatikan adalah menentukan tujuan dari pembelajaran tersebut. Penetapan tujuan dalam metode bercerita tidak lepas dari tujuan pembelajaran yang diawali dari indikator pembelajaran yang telah ditetapkan sebelumnya. Indikator yang telah ada sekaligus menjadi seleksi bagi seorang guru PAI atau calon guru lainnya dalam pemelihan metode pembelajaran yang tepat untuk diterapkan pada saat proses pembelajaran PAI.

Kedua, memilih jenis cerita. Seorang guru PAI tetap dituntut untuk menguasai penceritaan berbagai jenis dongeng tentunya dengan latihan yang dilakukan terus-menerus. Jenis cerita terkadang memang guru PAI yang menentukan, namun di sisi lain bila memang indikator pembelajaran PAI menceritakan kisah Nabi Ibrahim a,s, misalnya maka tidak dapat tidak seorang guru PAI harus menyesuaikan dengan indikator tersebut hingga tidak ada alasan lain untuk memilih jenis cerita yang sesuai. Di sini berarti terdapat dua hal penting dalam jenis cerita ini yaitu cerita di mana indikator pembelajarannya telah ditentukan jenis ceritanya, dan cerita di mana dalam indikator tidak disebutkan jenis ceritanya.

Ketiga, menyiapkan alat peraga. Alat peraga dalam bercerita sangat penting untuk dipersiapkan. Sebab bercerita itu dapat dibagi menjadi dua yaitu bercerita tanpa menggunakan alat peraga dan bercerita dengan menggunakan alat peraga. Di saat bercerita tanpa menggunakan alat peraga tentu tidak ada yang harus dipersiapkan terkait dengan alat peraga, hanya yang perlu dipersiapkan adalah suara yang baik dan stamina yang cukup. Sedang bercerita dengan menggunakan alat peraga, inilah yang harus dipersiapkan alat peranganya. Guru PAI yang baik dalam proses pembelajaran apapun sejatinya harus menggunakan alat peraga, demikian juga halnya dalam penggunaan metode bercerita.

Keempat, memperhatikan posisi duduk peserta didik. Ketika bercerita, yang diharapkan adalah perhatian para peserta didik dengan sepenuh hati dan pikiran mereka. Oleh karena itu guru harus dapat menguasai cerita yang disampaikan dengan baik. Ketika penceritaan berlangsung, para peserta didik hendaknya diposisikan secara khusus, tidak seperti waktu mereka belajar menulis dan membaca. Hubungan guru dengan para peserta didiknya dalam bercerita hendaknya seperti hubungan tuan rumah dengan tamuanya. Oleh karena itu, sangatlah dianjurkan bila posisi duduk para peserta didik dekat dengan guru. Posisi duduk yang baik bagi para peserta didik dalam mendengarkan cerita adalah berkumpul mengelilingi guru dengan 
posisi setengah lingkaran atau mendekati setengah lingkaran. Guru harus dapat memastikan bahwa para peserta didik merasa bebas jiwanya.Untuk dapat mengundang perhatian mereka, sebaliknya guru tidak langsung duduk ketika mulai bercerita, tetapi memulainya dengan berdiri, lalu pada menit-menit selanjutnya secara perlahan-lahan ia bersiap untuk duduk pada saat menyampaikan pembukaan cerita, kemudian setelah itu barulah ia duduk.

Kelima, menarik perhatian peserta didik dalam penyimakan. Penyimakan adalah pemahaman peserta didik secara penuh terhadap apa yang didengarnya dari kisah-kisah yang disampaikan oleh guru. Dalam ilmu jiwa, setiap kata atau ungkapan yang didengar atau dibaca oleh manusia akan memberi pengaruh dalam jiwanya, meliputi gambaran, arti, dan peristiwa seperti yang ia ingat dalam perjalanan hidupnya. Pengalaman setiap individu dalam memaknai gambaran, arti, dan peristiwa $\mathrm{j}$ el as ber beda sesuai kecerdasan masing-masing. Anak-anak pada usia dini sulit menahan perhatiannya dalam waktu yang lama. Mereka juga tidak akan bertahan lama duduk dalam satu tempat. Untuk itu, kami ingatkan agar guru PAI selalu memperhatikan hal-hal berikut: (1) Perhatian peserta didik timbul biasanya karena pengaruh cerita, rangkaian peristiwa, dan cara penyampaiannya. Keberlangsungan perhatian itu bergantung pada keinginan si peserta didik sendiri. (2) Sulit untuk membuat peserta didik tetap berada di satu tempat duduk sepanjang cerita berlangsung. Jika para peserta didik mulai terlihat bosan dan banyak bergerak maka guru harus mulai mencari penyebabnya. (3) Berbagai peristiwa dalam cerita haruslah merupakan satu rangkaian yang tidak terputus agar menjadi satu cerita yang utuh. (4) Dalam proses penyimakan, para peserta didik membayangkan diri mereka bermain bersama para tokoh dalam cerita dengan peran yang berbeda-beda. Merekaterlihat mulai khayalannyamengikuti jalannya cerita. (5) Di pertengahan penyimakan itu, para peserta didikjuga mengikuti perasaan guru yang bercerita dengan perasaan mereka sendiri, baik ketika sedih, gembira, atau marah. (6) Setelah mendengar cerita, para peserta didik diharapkan dapat menceritakan kembali sebagian atau seluruhnya dari cerita yang telah didengarnya, dengan menggunakan salah satu metode pengungkapan. (7) Cerita biasanya tidak membutuhkan peralatan menulis. Untuk itu, jika memungkinkan, guru bisa mengajak murid keluar kelas dan bercerita di udara bebas.

Keenam, menceritakan isi cerita dengan lengkap. Pada tahap ini, guru pendidikan agama Islam harus dengan jelas menceritakan cerita yang telah disusun dengan baik agar peserta didik dapat mengikuti secara maksimal. Sebuah cerita atau dongeng anak umumnya menyajikan alur dan tutur bahasa yang ringan dan menyenangkan, sehingga mudah dipahami anak. Gaya bercerita, intonasi, ekspresi dan pelafalan yang jelas merupakan bagian penting dalam bercerita yang dapat memudahkan penyerapan dan pemahaman anak akan nilai yang terkandung dalam cerita atau dongeng tersebut, serta berkembang-nya imajinasi anak. Efek fun dan learning yang terkandung dalam sebuah cerita atau dongeng merupakan energi, gambaran kekuatan sebuah cerita. Di samping itu, cara bercerita kita sebagai guru tentu lebih mengentalkan efek tersebut agar lebih disukai anak-anak. Bagaimana kita bercerita dan kekuatan apa yang terkandung dalam sebuah 
cerita hingga bisa memberikan manfaat bagi kepribadian anak? Cerita yang dilangsungkan haruslah dengan tenang, dengan dengan teknik sebagai berikut: (1) Memberikan lebih jelas mengenai seluruh rangkaian peristiwa dalam cerita; (2) Menceritakan jumlah tokoh dalam cerita dan membedakan masingmasing karakternya; (3) mengetahui berbagai emosi yang ada dalam cerita, seperti sedih, gembira, marah, kasihan, heran, lucu, dan sebagainya.

Ketujuh, menyimpulkan isi cerita. Isi dari cerita yang telah disampaikan sebelumnya secara bersama-sama guru PAI dengan peserta didik membuat kesimpulan. Kesimpulan yang diambil secara bersama-sama dimaksudkan untuk memberikan kesempatan kepada peserta didik memberikan kesimpulan terhadap materi yang dipelajari. Kesimpulan pembelajaran ini sangat penting artinya bagi peserta didik untuk memberikan pemahaman yang sama terhadap ceirta yang disampaikan sekaligus memberikan aspek-aspek penting yang harus diingat dan diteladani dalam kehidupan sehari-hari. Penyimpulan isi cerita ini dapat dilakukan dengan; guru PAI meminta satu atau dua orang peserta didik untuk memberikan pendapat apa yang diketahuinya sesuai dengan indikator yang ditetapkan; setelah itu guru merangkum pendapat-pendapat peserta didik tersebut dan meramunya menjadi sebuah kesimpulan dari cerita yang disampaikan.

Kedelapan, mengadakan evaluasi. Setelah secara bersama-sama menyimpulkan isi pembelajaran cerita maka tahap selanjutnya adalah mengevaluasi hasil pembelajaran yang diketahui oleh peserta didik. Evaluasi pembelajaran ini dimaksudkan untuk mengetahui tingkat penguasaan bahan pembelajaran peserta didik dengan menggunakan metode bercerita tersebut. Evaluasi pembelajaran ini dapat dilakukan dengan dua hal yaitu; evaluasi dengan menggunakan secara lisan; dan evaluasi dengan menggunakan secara tertulis. Evaluasi ini merupakan bagian dari terpenting dari perjalanan seorang guru dalam menwujudkan diri menjadi guru profesional. Bahkan salah satu ciri seorang guru professional adalah di mana guru tersebut selalu menggunakan evaluasi dalam setiap pembelajarannya. Guru pendidikan agama Islam harus mampu melakukan evaluasi sebagai bagian untuk memberikan umpan balik terhadap hasil cerita yang telah dilaksanakan. Evaluasi diperlukan untuk mengetahui tingkat pemahaman dan penguasaan peserta didik terhadap materi yang diajarkan melalui metode cerita tersebut. Di samping itu juga evaluasi diperlukan untuk memberikan umpan balik bagi guru terhadap efektifitas dan tingkat keberhasilan penggunaan metode yang dilangsungkan.

Kesembilan, tindak lanjut. Setelah guru PAI mengadakan evaluasi terhadap dua aspek penting di atas yaitu evaluasi terhadap penguasaan materi peserta didik dan evaluasi terhadap keberhasilan penggunaan metode maka langkah berikatunya adalah melakukan tindak lanjut. Tindak lanjut ini dapat dilakukan melalui hasil evaluasi dari kedua hal di atas. Bila memang ada peserta didik yang kurang dalam penguasaan materi pelajaran maka guru PAI harus mencari penyebab dan itu harus dieksekusi atau dilakukan perbaikan dengan cepat untuk pembelajaran berikutnya dengan metode bercerita tersebut.

\section{DAFTAR RUJUKAN}

Abdullah, Abdurrahman Saleh. 1994. Teori-Teori Pendidikan Berdasar- 
kan al-Qur'an, cet. 2. Jakarta: Rineka Cipta.

Akbarizan. 2008. Pendidikan Berbasis Akhlak. Pekanbaru: Suska Press.

Al-Hasyimi, Abdul Hamid. 2001. Mendidik Anak Ala Rasulullah, terj. Ibn Ibrahim. Jakarta: Pustaka Azzam.

Al-Qardhawi, Yusuf. 1994. Konsepsi Ilmu dalam Persepsi Rasulullah: Kerangka Dasar Metode Pengajaran. Jakarta: Firdaus.

Amini, Ibrahim, Agar Tidak Salah Mendidik Anak, terj. Ahmad Subandi dan Salman Fadhlullah; Salman Farisi (ed.), Jakarta: AlHuda, 2006

An-Nahlawi, Abdurrahman. 1992. Prinsip-Prinsip dan Metode Pendidikan Islam dalam Keluarga, Sekolah dan Masyarakat, terj. cet. 2. Bandung: Diponegoro.

Campbell, Linda, et. al., 2002. Multiple Intelligences: Metode Terbaru Melesatkan Kecerdasan, terj. Tim Inisiasi, cet. ke -1. Depok: Inisiasi Press.

Deden Saeful Ridhwan. MZ., "Analisa Penggunaan Metode Pengajaran Agama Islam", Jurnal Pendidikan dan Pemikiran Islam Istighna', STIT Islamic Village, Tangerang, Volume 2, No. 1, h. 66

Dhieni, Nurbiana, et. al., 2008. Materi Pokok Metode Pengembangan Bahasa, cet. 8. Jakarta: Universitas Terbuka.

Efendi, Onong Uchjana. 1993. Ilmu, Teori dan Filsafat Komunikasi, cet. 1. Bandung: Citra Aditya Bakti.

Ghuddah, 'Abdul Fattah Abu. tt. ar-Rasul al-Mu'allim Shallallhu 'Alaihi Wasallam wa Asalibihi fi al-Ta'lim. tp: Maktab al-Mathbu'at alIslamiyah.

Hafizh, Muhammad Nur Abdul. 1998. Mendidik Anak Bersama
Rasulullah. Bandung: al-BayanMizan.

Hafizh, Muhammad Nur Abdul. 1998. Mendidik Anak Bersama Rasulullah, cet. 3. Jakarta: al-Bayan Bekerjasama dengan Mizan.

Hidayat, Otib Satibi. 2006. Materi Pokok Metode Pengembangan Moral dan Nilai-Nilai Agama, cet. 6. Jakarta: Universitas Terbuka.

Jaliluddin. 1998. Psikologi Agama. Jakarta: Raja Grafindo Persada.

Laksana, Indra, et. al., 2010. Syamil alQur'an Miracle The Reference, cet. 1. Bandung: Sygma Publishing.

Manzhur, Ibn. 711 H. Lisan al-Arab. Beirut-Libnan: Dar al-Tustsi al'Arabi.

Nata, Abuddin. 2001. Filsafat Pendidikan Islam, cet. 4. Jakarta: Logos Wacana Ilmu.

Nizar, Samsul dan Zaenal Efendi Hasibuan. 2011. Hadis Tarbawi: Membangun Kerangka Pendidikan Ideal Perspektif Rasulullah, , cet. ke -1. Jakarta: Kalam Mulia.

Qutb, Muhammad. 1993. Sistem Pendidikan Islam, iterj. Salman Harun. Bandung: al-Ma'arif.

Qutb, Muhammad. 1993. Sistem Pendidikan Islam, terj. Salman Harun. Bandung: al-Ma'arif.

Shihab, M. Quraish. 2012. Tafsir alMishbah, Pesan, Kesan, dan Keserasian al-Qur'an Volume 6, cet. V. Jakarta: Lentera Hati.

Supriyono, Widodo, "Imu Pendidikan Islam: Teoritis dan Praktis", dalam, Ismail SM, et. al., (ed.). 2001. Paradigma Pendidikan Islam, Yogyakarta: Pustaka Pelajar dan Fakultas Tarbiyah IAIN Wali Songo.

Uhbiyati, Nur dan Abu Ahmadi. 1997. Ilmu Pendidikan Islam. Bandung: Pustaka Setia.

Uhbiyati, Nur. 1997. Ilmu Pendidikan Islam 2. Bandung: Pustaka Setia. 
